\title{
Basophils control T-cell responses and limit disease activity in experimental murine colitis
}

\author{
M Rodriguez Gomez ${ }^{1}$, Y Talke ${ }^{1}$, C Hofmann ${ }^{2}$, I Ketelsen ${ }^{1}$, F Hermann ${ }^{1}$, B Reich ${ }^{1}$, N Goebel ${ }^{1}$, \\ K Schmidbauer ${ }^{1}, \mathrm{~N}_{\text {Dunger }}{ }^{2}, \mathrm{H}_{\text {Brühl }}{ }^{2}$, K Renner ${ }^{1}, \mathrm{~S}-\mathrm{N}$ Syed ${ }^{1}$ and M Mack ${ }^{1}$
}

Basophils have been recognized as important inducers of T helper type 2 (Th2) responses. Using the colitis model of adoptive transfer of $\mathrm{CD}^{+} \mathrm{CD}^{+} \mathrm{L}^{+} \mathrm{T}$ cells into lymphopenic hosts, we have analyzed how basophils regulate T-cell responses and modulate disease activity. Transferred T cells rapidly proliferate, produce large amounts of interleukin (IL)-3, and expand the number of basophils in an IL-3-dependent manner. Depletion of basophils with two different antibodies substantially upregulated Th1 cytokines in transferred T cells at day 8. Increased Th1 cytokine expression persisted until the end of the experiment when basophil-depleted mice showed exacerbation of colitis with more severe loss of weight, histological damage, colonic leukocyte infiltration, and expression of pro-inflammatory cytokines. In vitro, we show that basophil-derived IL-4 and IL-6 downregulates expression of interferon- $\gamma$, IL-2, and tumor necrosis factor in T cells. These data show a beneficial role of basophils in a T-cell driven model of autoimmunity.

\section{INTRODUCTION}

Basophils develop from a common granulocyte-monocyte progenitor in the bone marrow and represent the least abundant leukocyte subset in the circulation $(0.1-0.3 \%){ }^{1}$ The role of basophils for host immunity has long been underestimated owing to difficulties in their identification and modulation. Increasing attention is now drawn to their role in regulation of adaptive immune responses, as basophils readily release large quantities of interleukin (IL)-4 and IL-6 and support development of $\mathrm{T}$ helper type 2 (Th2) responses. ${ }^{2-7}$ Several publications provide evidence that basophils cooperate with antigen-presenting $\mathrm{MHC}$ (major histocompatibility complex)II-positive dendritic cells for induction of Th2 cells. ${ }^{4-8-11}$ A large variety of substances have been described to induce cytokine release by basophils. The two most important pathways for activation of murine basophils are stimulation with IL-3 and crosslinkage of FceR1 by binding of antigen to surface-bound immunoglobulin E. ${ }^{12-15}$ The main source of IL-3 are CD4 ${ }^{+} \mathrm{T}$ cells, which support basophil expansion following infection. ${ }^{12,16-18}$ IL-3 activates basophils and is able to prolong their survival at very low concentrations. ${ }^{19-21}$

Crohn's disease and ulcerative colitis constitute a chronic inflammation of the intestine and are collectively known as inflammatory bowel disease. ${ }^{22,23}$ Adoptive transfer of naive $\mathrm{CD}^{+}{ }^{+} \mathrm{T}$ cells in T-cell-deficient mice (e.g., SCID or RAG ${ }^{-/-}$ mice) is a well-established model of colitis ${ }^{24}$ exhibiting many of the clinical and histological features of human inflammatory bowel disease. Several experiments suggest that colitis is largely mediated by preferential expansion of colitogenic pro-inflammatory Th1 cells expressing interferon (IFN) $-\gamma$ and tumor necrosis factor (TNF). Colitis could not be induced by adoptive transfer of $\mathrm{T}$ cells from IFN- $\gamma$-deficient mice ${ }^{25}$ and was efficiently suppressed with monoclonal antibodies against TNF. $^{26,27}$ Also IL-12, a major inducer of Th1 and IL-23, was shown to be critical for development of colitis. ${ }^{28,29}$ Overexpression of the Th1-related transcription factor STAT4 (signal transducer and activator of transcription factor 4) or deficiency of IL-10 resulted in spontaneous development of colitis. ${ }^{30-32}$ Recent studies showed that basophils promote Th2 immunity in a Th2-impaired environment, suggesting that basophils could be beneficial in pro-inflammatory Th1 disorders. $^{33,34}$ In addition, it was shown that commensal microbiota in the gut suppress basophil development indicating a role of the intestine for basophil homeostasis and Th1-Th2 regulation. ${ }^{35}$ Basophils markedly increase the release of IL-4, IL-13, and IL-10 from activated CD $4^{+} \mathrm{T}$ cells in an

${ }^{1}$ Department of Internal Medicine II, University Hospital Regensburg, Regensburg, Germany and ${ }^{2}$ Department of Internal Medicine I, University Hospital Regensburg, Regensburg, Germany. Correspondence: M Mack (matthias.mack@klinik.uni-regensburg.de) 
IL-4- and IL-6-dependent manner while Th1 cytokine production (IL-2, IFN- $\gamma$ ) is suppressed. ${ }^{2-7,13}$ Basophils not only alter the phenotype of $\mathrm{CD}^{+}{ }^{+} \mathrm{T}$ cells but also provide important help for humoral memory immune responses. ${ }^{13,36-38}$ Consequently in murine models of collagen-induced arthritis ${ }^{20}$ and lupus nephritis, ${ }^{39}$ basophils contribute to autoantibody production and disease activity. Lymphopenic SCID and $\mathrm{RAG}^{-1-}$ mice offer the possibility to investigate the impact of basophils on a T-cell driven disease without effects of the humoral immune system. We hypothesized that basophils alter the phenotype of $\mathrm{T}$ cells during their early expansion in lymphopenic hosts and suppress development of colitis. We a
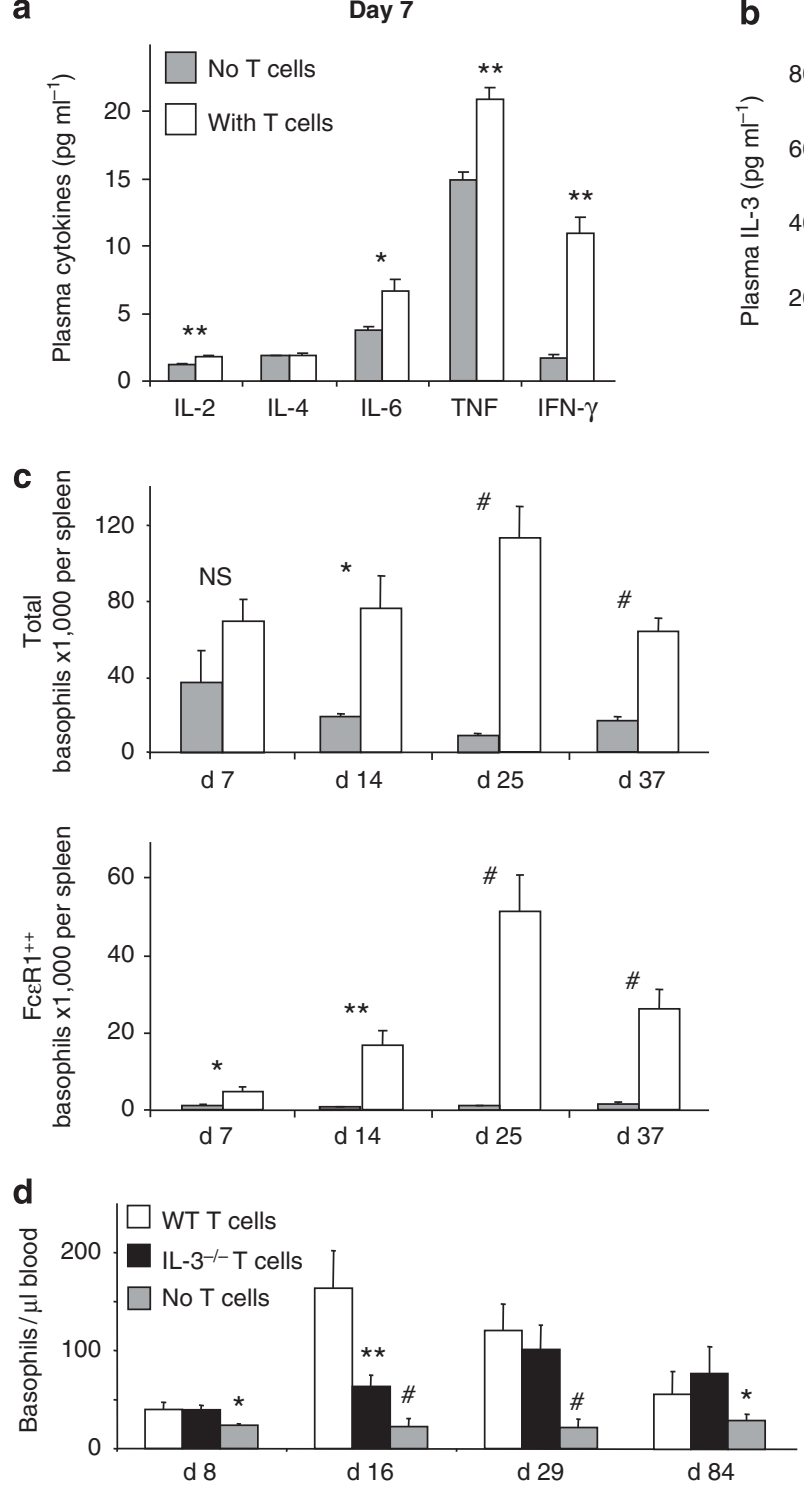

show that adoptively transferred $\mathrm{T}$ cells produce large amounts of IL-3, which leads to expansion of basophils. Depletion of basophils before adoptive transfer of $\mathrm{T}$ cells increased Th1 cytokine expression in $\mathrm{T}$ cells and resulted in exacerbation of colitis, indicating that basophils have a protective role in a Th1-driven model of autoimmunity.

\section{RESULTS}

\section{Characterization of basophils in lymphopenic mice}

Lymphopenic SCID mice are deficient in T and B cells but show normal numbers of basophils (approximately 25 basophils per $\mu$ lblood). We investigated whether reconstitution of SCID mice
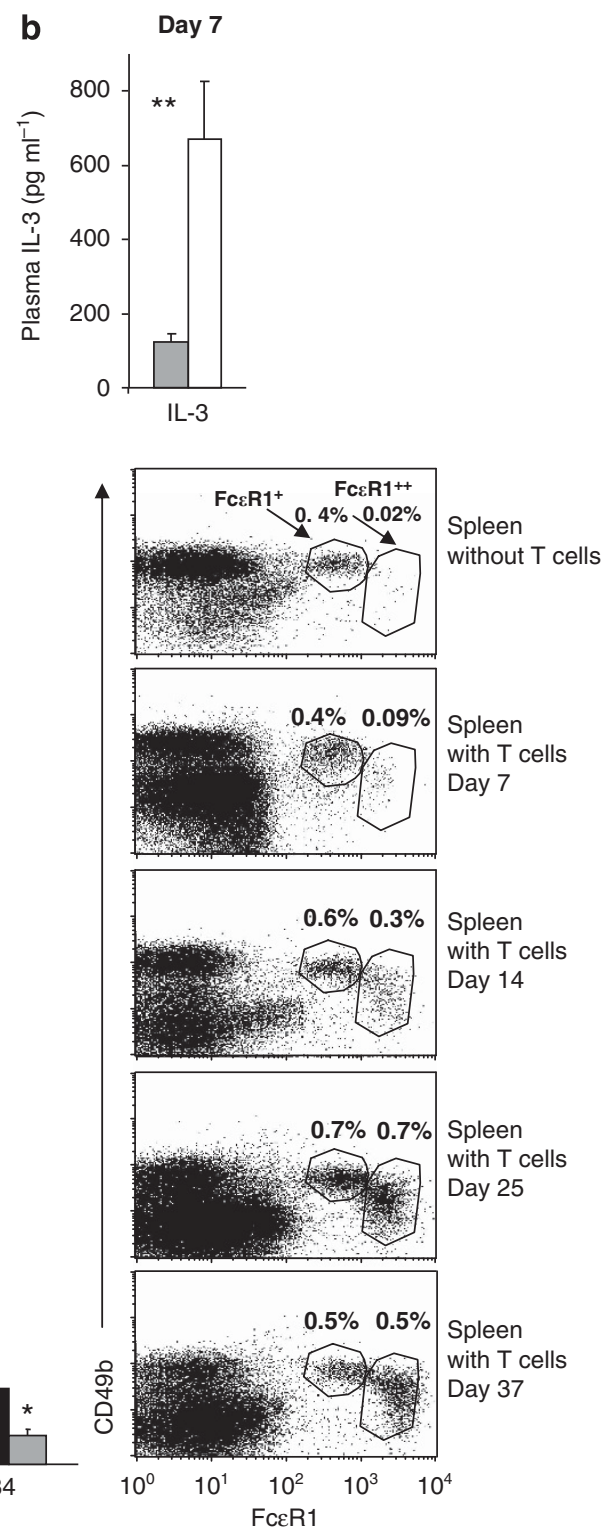

Figure 1 Characterization of basophils after reconstitution of SCID mice with CD4 ${ }^{+}$CD62L ${ }^{+}$T cells. (a-c) SCID mice $(n=6 /$ group $)$ were reconstituted with $2 \times 10^{6} \mathrm{CD}^{+}{ }^{+} \mathrm{CD} 62 \mathrm{~L}^{+} \mathrm{T}$ cells from BALB/c mice (white bars) or received just phosphate-buffered saline without T cells (grey bars) and analyzed 7 days later. (a) Plasma cytokine levels were quantified by cytometric bead array. (b) The plasma level of interleukin (IL)-3 was measured by in vivo cytokine capture assay. (c) By staining with antibodies against $F_{C \varepsilon R} 1$ and $C D 49 b$, the numbers of $F_{C \varepsilon R} 1^{+}$and $F_{c \varepsilon R} 1^{++}$basophils were quantified in the spleen of SCID mice 7, 14, 25, and 35 days after reconstitution with $\mathrm{CD} 4{ }^{+} \mathrm{CD} 62 \mathrm{~L}^{+} \mathrm{T}$ cells from BALB/c mice. (d) SCID mice were adoptively transferred with $0.5 \times 10^{6} \mathrm{CD}^{+}{ }^{+} \mathrm{CD} 62 \mathrm{~L}^{+} \mathrm{T}$ cells from BALB/c mice (white bars) or IL-3-deficient mice (black bars) (nine mice per group). The control group received no T cells (grey bars; 10 mice per group). After $8,16,29$, and 84 days, basophils were quantified in the peripheral blood by flow cytometry with counting beads. Data are represented as mean \pm s.e.m. IFN, interferon; TNF, tumor necrosis factor; WT, wild type. 
with $\mathrm{CD} 4^{+} \mathrm{T}$ cells affects plasma cytokine levels and the frequency of basophils. Reconstitution of mice with $\mathrm{CD} 4^{+} \mathrm{T}$ cells induced a pro-inflammatory plasma cytokine milieu with increased levels of IL-2, IL-6, TNF, and IFN- $\gamma$ on day 7 (Figure 1a). Also plasma levels of IL-3, which is known to activate and expand basophils, are increased more than fivefold after transfer of $\mathrm{T}$ cells (Figure 1b). At various time points after reconstitution of SCID mice with $\mathrm{CD} 4{ }^{+} \mathrm{CD}_{2} \mathrm{~L}^{+} \mathrm{T}$ cells, we quantified the absolute and relative numbers of basophils in the spleen, bone marrow, and peripheral blood. Total basophils and especially a subpopulation of $\mathrm{F}_{\mathcal{C} \varepsilon \mathrm{R}} 1^{++}$basophils were markedly increased after reconstitution with $\mathrm{T}$ cells. In the spleen the most pronounced increase of basophils was seen on day 25 , while in the bone marrow the increase started earlier and was already prominent at day 7 (Figure 1c, Supplementary Figure S1). In the peripheral blood, the most pronounced increase of basophils was observed on days 16 and 29 (Figure 1d and Supplementary Figure S2). We also show that reconstitution with T cells from IL- $3^{-1-}$ mice delays the increase in basophils (day 16), indicating that IL-3 contributes to the increase of basophils in vivo. Reconstitution with wildtype $\mathrm{T}$ cells also increased the number of basophils in the mesenteric lymph nodes and the colon as measured on day 37 (Supplementary Figure S3).

To show that the adoptively transferred $\mathrm{T}$ cells not only expand but also activate basophils, we reconstituted SCID mice with $\mathrm{CD} 4{ }^{+} \mathrm{CD} 62 \mathrm{~L}^{+} \mathrm{T}$ cells from wild-type and IL- $3^{-1-}$ mice or just injected phosphate-buffered saline as control (no T cells). Fourteen days later, splenocytes and bone marrow cells ( 2 Mio cells per well) were cultured overnight without stimulation to measure spontaneous cytokine release or were stimulated with IL-3 to measure induced cytokine release. To demonstrate that basophils are the source of IL-4 and IL-6, we also cultured splenocytes and bone marrow cells that were depleted of basophils with magnetic beads. Total splenocytes from SCID mice reconstituted with wild-type $T$ cells released high amounts of IL-4 and IL-6, which was dependent on the presence of basophils (Figure 2 and Supplementary Figure S4). Addition of IL-3 did not further enhance the release of IL-4, indicating that the basophils are already fully activated under basal conditions. By contrast, splenocytes from SCID mice not reconstituted with $\mathrm{T}$ cells produced almost no IL- 4 and much less IL-6, and the cytokine release could be stimulated with IL-3. Splenocytes from SCID mice reconstituted with IL-3 ${ }^{-1-}$ T cells spontaneously produce much less IL- 4 and IL- 6 than splenocytes from mice reconstituted with wild-type $T$ cells. This indicates that T-cell-derived IL-3 has an important role for activation of basophils in the spleen. In the bone marrow, the IL-4 release was similar to the spleen, but the spontaneous release of IL-4 was much lower than the IL-3-induced release, reflecting a lower baseline activation of basophils in the bone marrow.

Interestingly among the expanded basophils, a population of cells with higher levels of Fc\&R1 $\left(\mathrm{Fc \varepsilon R} 1^{++}\right)$and somewhat lower levels of $\mathrm{CD} 49 \mathrm{~b}$ became detectable in the spleen and bone marrow (Figure 1c). This population of Fc\&R1 ${ }^{++} \mathrm{CD}_{4} 9 \mathrm{~b}^{+}$
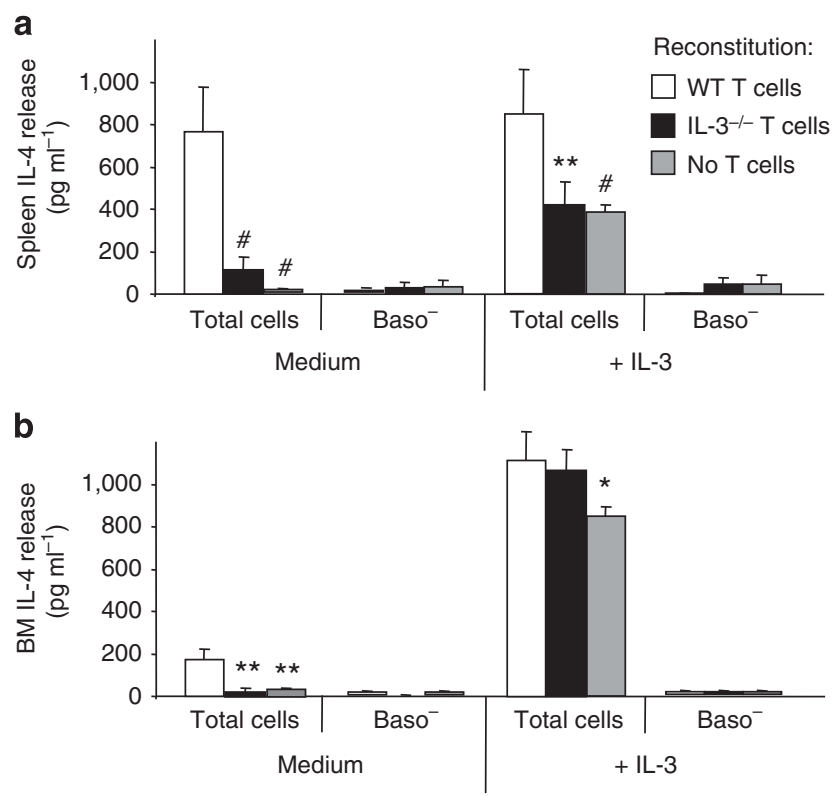

Figure 2 Ex vivo analysis of interleukin (IL)-4 release by basophils after reconstitution of SCID mice with $\mathrm{CD}^{+}{ }^{+} \mathrm{CD}_{2} \mathrm{~L}^{+}{ }^{+} \mathrm{T}$ cells. $(\mathbf{a}, \mathbf{b}) \mathrm{SCID}$ mice were reconstituted with $2 \times 10^{6} \mathrm{CD} 4{ }^{+} \mathrm{CD}_{22} \mathrm{~L}^{+} \mathrm{T}$ cells from BALB/c mice (white bars) or IL-3 $3^{-1-}$ mice (black bars) or received no T cells (grey bars; four mice per group). After 14 days, splenocytes (a) or bone marrow (BM) cells (b) were obtained. Total cells or cells depleted of basophils in vitro $\left(\right.$ Baso $\left.^{-}\right)$were cultured for $12 \mathrm{~h}$ in medium alone (Medium) or in medium with IL-3 (+ IL-3; $2 \times 10^{6}$ cells in $\left.200 \mu \mathrm{l}\right)$. The concentration of IL-4 was measured by enzyme-linked immunosorbent assay. Data are represented as mean \pm s.e.m. WT, wild type.

cells accounted mostly for the overall increase of basophils after reconstitution with T cells. We characterized the Fc\&R1 ${ }^{+}$and FcER1 ${ }^{+}+$cell populations after FACS (fluorescence-activated cell sorter)-sort (Supplementary Figure S5). Both cell types showed typical properties of basophils, as they released large quantities of IL-4 and IL-6, induced proliferation of B cells, upregulated IL-10, and downregulated IFN- $\gamma$ production in $\mathrm{CD}^{+} \mathrm{T}$ cells (Supplementary Figure S5). The newly generated $\mathrm{FccR} 1^{++}$basophils were more potent than FceR $1^{+}$cells and induced phenotypic changes in both $\mathrm{B}$ and $\mathrm{CD} 4^{+} \mathrm{T}$ cells at lower cell numbers.

\section{Depletion of basophils enhances the pro-inflammatory Th1 phenotype in adoptively transferred $\mathrm{T}$ cells}

SCID mice were treated for 3 days twice daily with $5 \mu \mathrm{g}$ of the FceR1-specific antibody MAR1 and reconstituted with $\mathrm{CD} 4^{+}$ $\mathrm{CD}_{2} \mathrm{~L}^{+} \mathrm{T}$ cells 2 days after the last injection of MAR1. Treatment with MAR1 completely depleted basophils in the spleen and peripheral blood at day 8 after reconstitution (Figure 3a). Basophils were still significantly reduced at day 20 but returned to control levels at day 27 (Figure 3b). Basophils were identified by expression of CD $49 \mathrm{~b}$ and CD $45 .{ }^{13}$ Based on a recent report describing the appearance of Fc\&R1 ${ }^{+} \mathrm{CD} 11 \mathrm{c}^{+}$ $\mathrm{CD} 49 \mathrm{~b}^{-}$inflammatory dendritic cells in the mediastinal lymph nodes of mice after intranasal exposure to dust mite allergens, ${ }^{8}$ we investigated whether these inflammatory DCs exists in SCID and $\mathrm{RAG}^{-/-}$mice. As shown in 
a

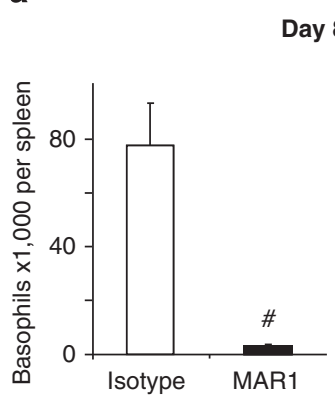

Day 8

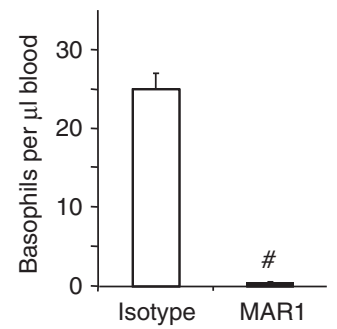

Day 20
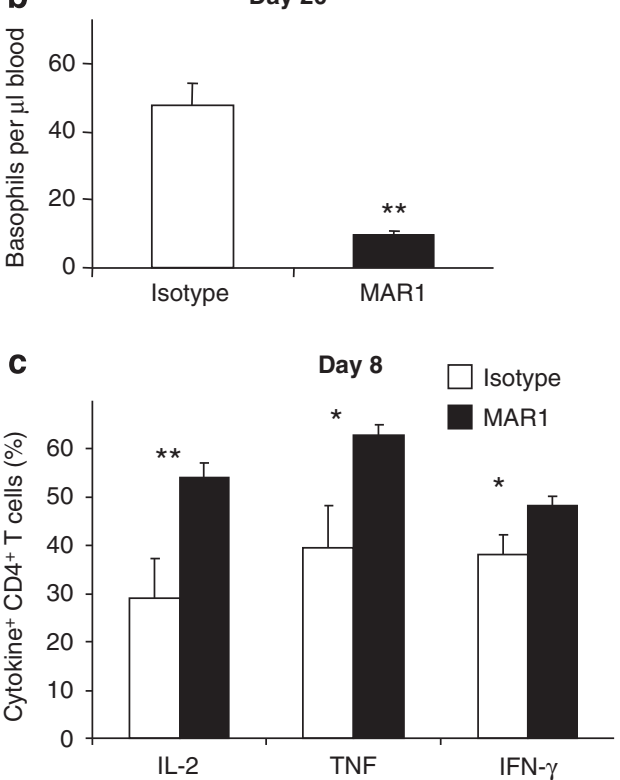

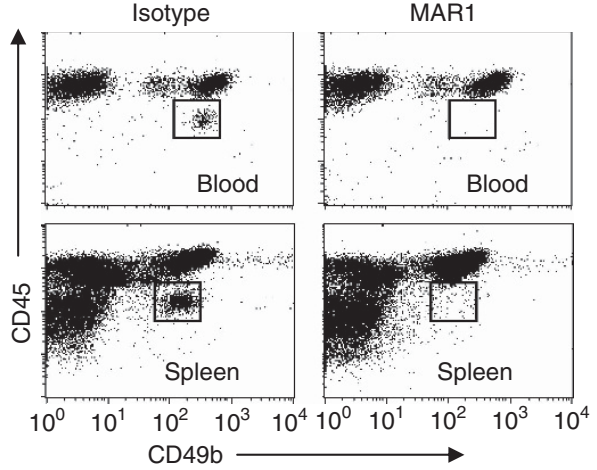

Day 27
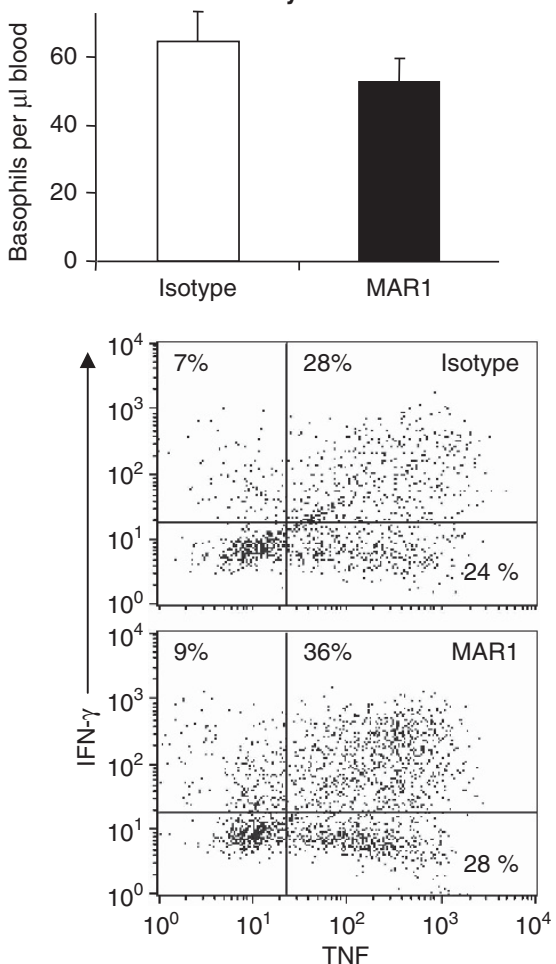

Figure 3 Depletion of basophils with the antibody MAR1 enhances the T helper type 1 phenotype of adoptively transferred T cells. (a-d) SCID mice (nine mice per group) were treated twice daily intraperitoneally with $5 \mu \mathrm{g}$ of the antibody anti-FcER1 (MAR1) or the isotype control antibody (Isotype) for 3 days, and $2 \times 10^{6} \mathrm{CD} 4{ }^{+} \mathrm{CD} 62 \mathrm{~L}^{+} \mathrm{T}$ cells from BALB/c mice were adoptively transferred 2 days after the last antibody injection (= day 0$)$. (a) Basophils (gated cells) were identified by expression of CD45 and CD49b and quantified by flow cytometry with counting beads in spleen and blood on day 8 (10 mice per group). (b) After treatment with MAR1, basophils were significantly reduced in the peripheral blood of the SCID mice until day 20 but returned on day 27. (c) On day 8 after T-cell transfer, intracellular cytokine expression of splenic CD4 ${ }^{+}$T cells from basophil-depleted mice (black bars) and isotypetreated mice (white bars) (nine mice per group) was quantified by flow cytometry. One out of three representative experiments is shown. Data are represented as mean \pm s.e.m. IFN, interferon; IL, interleukin; TNF, tumor necrosis factor.

Supplementary Figure S6, no CD11c ${ }^{+} \mathrm{FcER} 1^{+}$dendritic cells could be detected in the spleen or bone marrow. To investigate how the presence or absence of basophils alters the phenotype of $\mathrm{CD}^{+}{ }^{+} \mathrm{T}$ cells during early expansion in SCID mice, we analyzed intracellular cytokine expression of splenic $\mathrm{CD} 4{ }^{+} \mathrm{T}$ cells on day 8 after adoptive transfer (Figure $3 \mathrm{c}$ ). $\mathrm{CD} 4^{+} \mathrm{T}$ cells transferred in basophil-depleted mice showed a significantly higher intracellular expression of pro-inflammatory IL-2, TNF, and IFN- $\gamma$ than $\mathrm{CD}^{+}{ }^{+} \mathrm{T}$ cells from control mice. The total number of splenic $\mathrm{CD} 4^{+} \mathrm{T}$ cells was not altered by depletion of basophils (data not shown).
To exclude potential unspecific effects of the MAR1 antibody, we used the antibody Ba103, directed against CD200R3, as an alternative method for depletion of basophils (Figure 4a). In contrast to MAR1, the antibody BA103 was also described to not affect mast cells, ${ }^{40}$ which we have confirmed in SCID mice (Supplementary Figure S7). SCID mice were injected with $30 \mu \mathrm{g}$ of Ba103 on day -3 , and $\mathrm{T}$ cells were adoptively transferred on day 0. Injection of Ba103 markedly reduced the number of basophils as measured on day 8 in the spleen and peripheral blood. In a separate experiment, blood was drawn until day 13 and showed a significant reduction of 
a

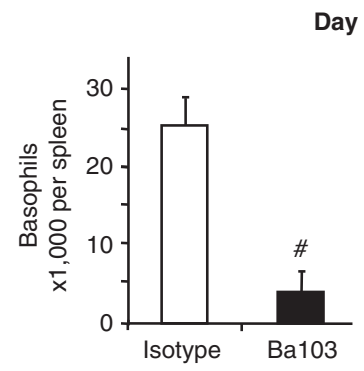

Isotype

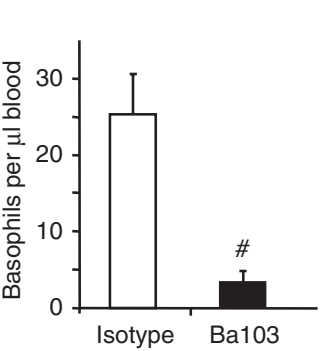

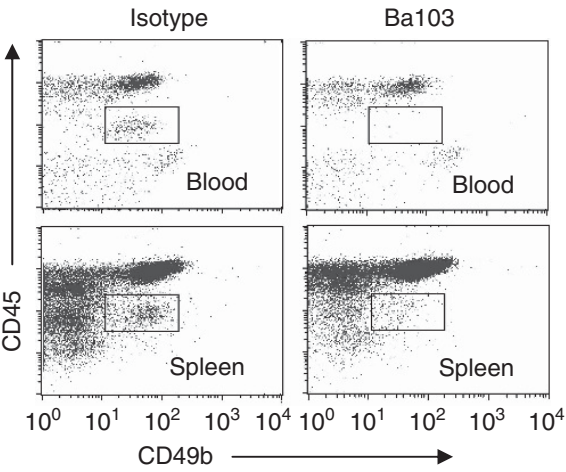

b

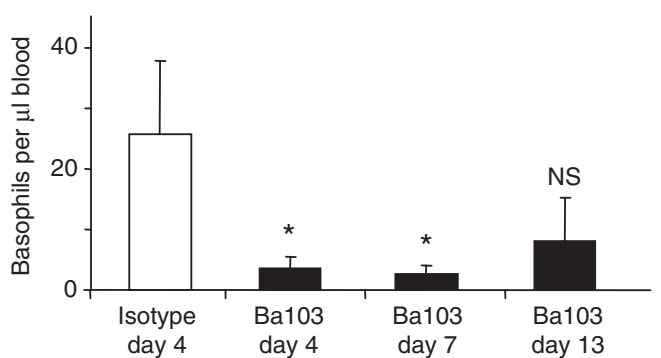

C

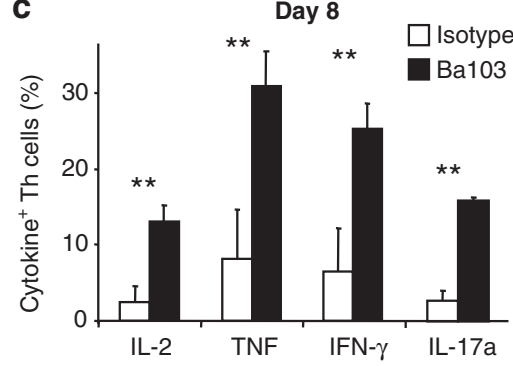

d

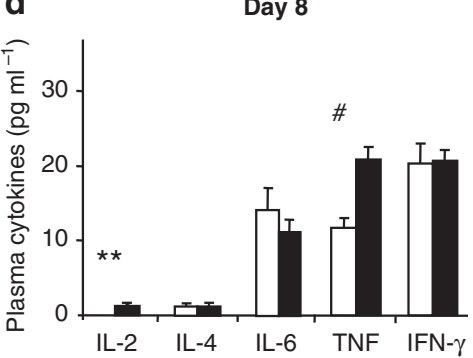

Figure 4 Depletion of basophils with the antibody Ba103 enhances the T helper type 1 (Th1) phenotype of adoptively transferred T cells. (a, b) SCID mice received a single intravenous injection of $30 \mu \mathrm{g}$ CD200R3 antibody Ba103 (black bars) or an isotype control antibody (white bars). (a) Basophils were identified by expression of CD45 and CD49b and quantified by flow cytometry with counting beads in spleen and blood on day 8 (nine mice per group). (b) After treatment with Ba103, basophils were significantly reduced in the peripheral blood of the SCID mice until day 7 but returned on day 13 . (c, d) Basophils were depleted in SCID mice by a single injection of the antibody Ba103 (black bars) or remained undepleted (white bars), and $2 \times 10^{6}$ $\mathrm{CD}^{+}{ }^{+} \mathrm{CD} 62 \mathrm{~L}^{+} \mathrm{T}$ cells from BALB/c mice were adoptively transferred 3 days later (nine mice per group). On day 8 after T-cell transfer, intracellular cytokine expression of $\mathrm{CD} 4{ }^{+} \mathrm{T}$ cells from mesenteric lymph nodes was quantified by flow cytometry (c) and plasma cytokines were measured by enzyme-linked immunosorbent assay (d). One out of two representative experiments is shown. Data are represented as mean \pm s.e.m. IFN, interferon; IL, interleukin; TNF, tumor necrosis factor.

basophils until day 7, with a return at day 13 (Figure $4 \mathbf{b}$ ). On day 8 after adoptive transfer of $\mathrm{T}$ cells, we analyzed how the absence of basophils alters plasma cytokine levels and the phenotype of the T cells. Compared with the control group, the basophil-depleted mice showed elevated levels of IL-2 and TNF in the plasma and a threefold increase of the intracellular cytokines IL-2, TNF, IFN- $\gamma$, and IL-17 in $\mathrm{CD}^{+}{ }^{+} \mathrm{T}$ cells (Figure 4c,d).

\section{Depletion of basophils aggravates experimental colitis in lymphopenic mice}

To address the question whether basophil-dependent early changes in T-cell cytokine expression has an impact on the development of colitis, we depleted basophils in SCID mice by injection of the MAR1 antibody from day -4 to day -2 and adoptively transferred $\mathrm{CD} 4{ }^{+} \mathrm{CD}_{2} \mathrm{~L}^{+} \mathrm{T}$ cells on day 0 . As shown in Figure 5a, the weight of control mice increased until day 31 , with a subsequent slow decline until day 84 . By contrast, there was a significant drop of weight in basophil-depleted mice from day 18 to day 84 . Histological analysis of colon tissue on day 84 showed significantly more epithelial damage with extensive loss of goblet cells, a higher infiltration of inflammatory cells into the submucosa and lamina propria as well as more pronounced crypt destruction and circumferential inflammation in basophil-depleted mice
(Figure 5d). Flow cytometric analysis of single-cell suspensions of colon tissue revealed a significant increase of leukocytes and $\mathrm{CD}^{+} \mathrm{T}$ cells in basophil-depleted mice (Figure 5b,c). Similarly, the mesenteric lymph nodes of basophil-depleted mice contained about two times more leukocytes and $\mathrm{CD}^{+} \mathrm{T}$ cells than controls, while the number of splenic $\mathrm{CD}^{+} \mathrm{T}$ cells remained unchanged (data not shown). Plasma levels of TNF and IL-6 were significantly higher in basophil-depleted mice (Figure 6a). Colonic cytokine mRNA levels of the pro-inflammatory cytokines TNF, IL-6, IFN- $\gamma$, and IL-17a were significantly increased in basophil-depleted mice, whereas IL-4 and IL-10 remained unchanged (Figure $\mathbf{6 b}$ ).

In a separate experiment, we depleted basophils and reconstituted the mice with $\mathrm{T}$ cells as described above and already analyzed them on day 25 (Supplementary Figure S8). At this time point, there was little weight loss in all the groups and no difference between basophil-depleted and non-depleted mice in colonic histology. However, mice depleted of basophils showed a higher percentage of $\mathrm{CD} 4{ }^{+} \mathrm{T}$ cells expressing IFN- $\gamma$, TNF, IL-17a, and IL-2, similar to what we have observed on day 8 (see Figure 3), indicating that Th1 responses amplified by depletion of basophils persist for prolonged periods of time. Most likely increased colitis in basophil-depleted mice develops over time due to persistently increased Th1 responses. 
a

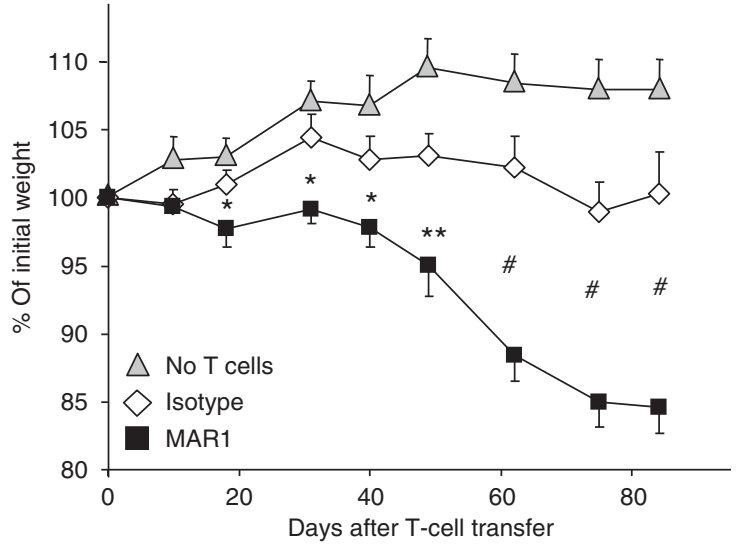

C

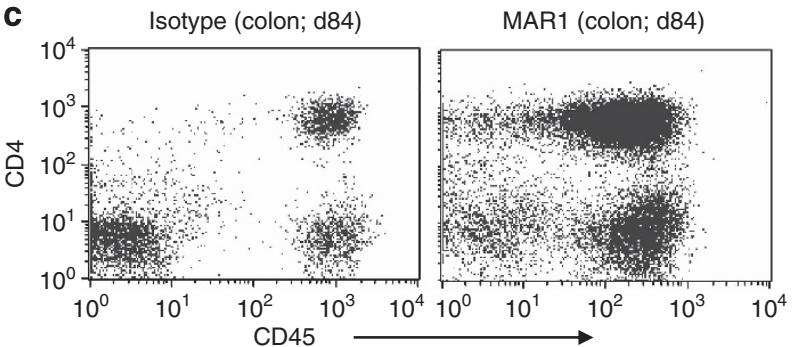

b
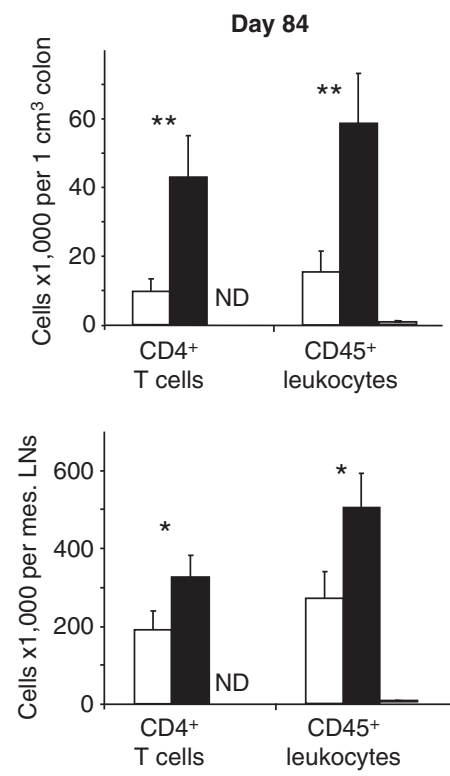

$\square$ Isotype $\square$ MAR1 $\square$ No T cells d

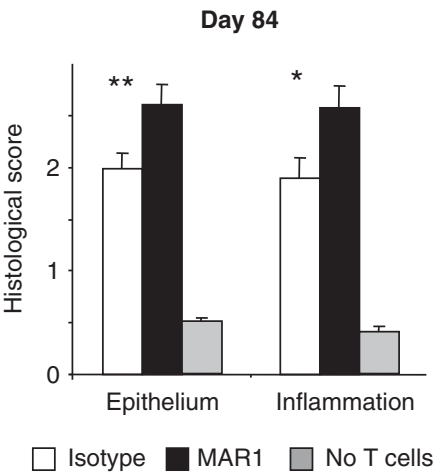

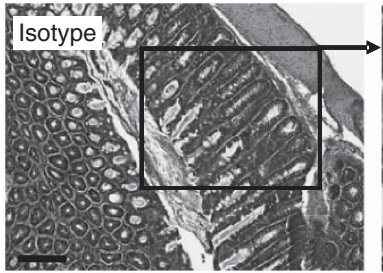
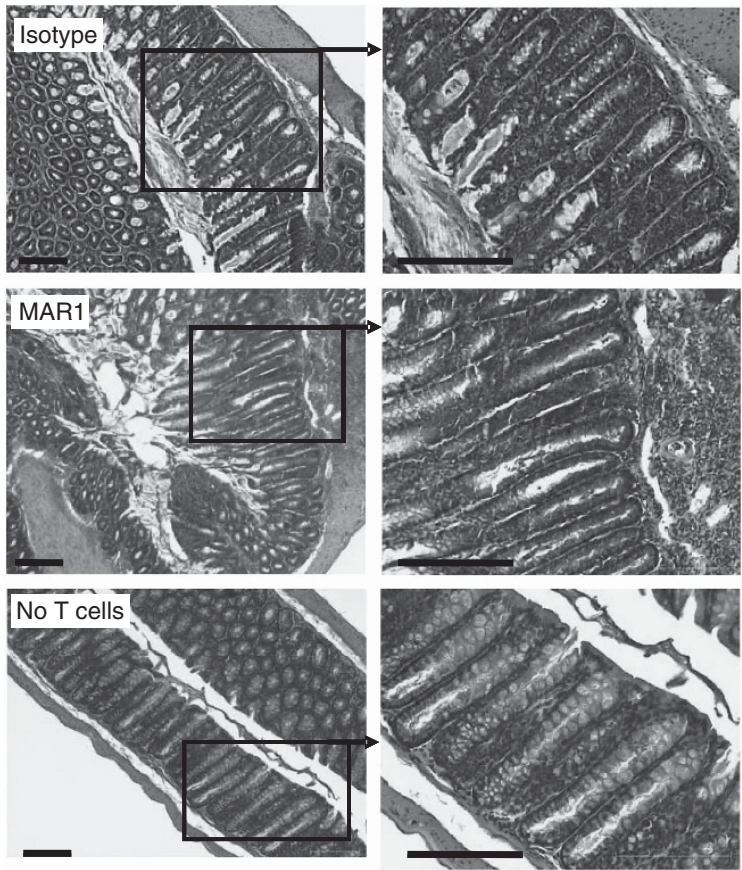

Figure 5 Depletion of basophils with MAR1 aggravates colitis in SCID mice. (a-d) Basophils were depleted in SCID mice by injections of the antibody MAR1 (black bars) or remained undepleted (white bars) (11 mice per group). In all, $0.5 \times 10^{6} \mathrm{CD}^{+}{ }^{+} \mathrm{CD}_{22} \mathrm{~L}^{+} \mathrm{T}$ cells from BALB/c mice were adoptively transferred 2 days later $(=$ day 0$)$ to induce colitis and mice were monitored until day 84 . A control group received no $T$ cells (injection of phosphatebuffered saline; grey bars; four SCID mice). (a) The weight of the mice was measured until day 84 . One out of three representative experiments is shown. (b, c) Flow cytometric analysis of colon tissue and mesenteric lymph nodes (mes. LNs) of initially basophil-depleted mice (black bars; MAR1) and isotypetreated mice (white bars; Isotype). Leukocytes were identified by expression of CD45. The majority of infiltrating leukocytes consisted of CD4 ${ }^{+} \mathrm{T}_{\text {cells. }}$ (d) Histological analysis of colon tissue to quantify epithelial damage and inflammation. Bars $=100 \mu \mathrm{m}$. Data are represented as mean \pm s.e.m. ND, not detected.

The impact of basophils in experimental colitis could also be confirmed with RAG2 ${ }^{-1-}$ mice on a B6 background using a different antibody for depletion of basophils. Basophils were depleted on day -3 by injection of Ba103 or received an isotype control antibody. $\mathrm{CD} 4{ }^{+} \mathrm{CD} 62 \mathrm{~L}^{+} \mathrm{T}$ cells from C57BL/6 mice were adoptively transferred on day 0 . In addition, we included a third group of mice that did not receive T cells or antibodies to deplete basophils. Depletion of basophils in T-cell reconstituted 

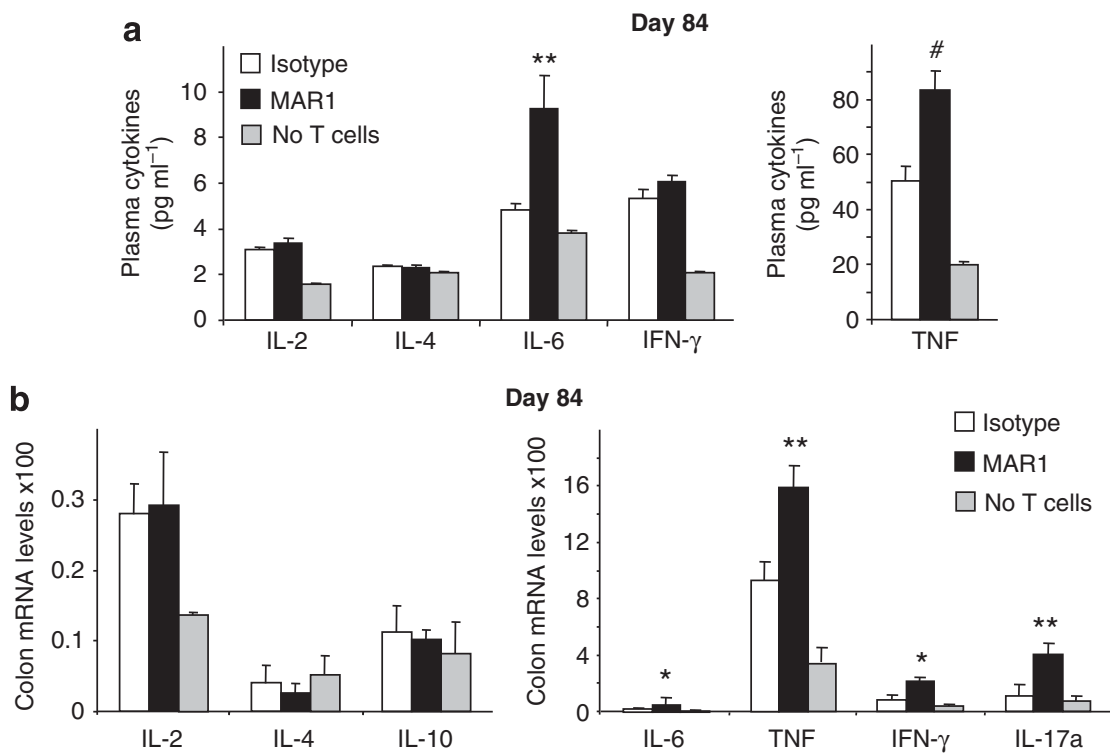

Figure 6 Analysis of cytokines in the plasma and colon at day 84 after induction of colitis. (a, b) On day 84 after induction of colitis as described in Figure 5, plasma cytokine levels were measured with a cytometric bead array. Cytokine expression in colon tissue was quantified by real-time PCR. One out of two representative experiments is shown. Data are represented as mean \pm s.e.m. IFN, interferon; IL, interleukin; TNF, tumor necrosis factor.

mice led to a significantly more pronounced loss of weight than treatment with the control antibody. By contrast, no weight loss was detectable in mice that did not receive T cells (Figure 7a). The histological analysis of colon tissue on day 70 demonstrated significantly more epithelial damage and a higher infiltration of inflammatory cells in basophil-depleted mice compared with the control groups (Figure 7b). Basophildepleted mice also contained more leukocytes and $\mathrm{CD} 4{ }^{+} \mathrm{T}$ cells in the mesenteric lymph nodes and colon as well as higher levels of IL-2, IFN- $\gamma$, and TNF in the plasma (Figure 7c,d). On day $70, \mathrm{CD} 4^{+} \mathrm{T}$ cells from mesenteric lymph nodes expressed significantly more IL-2 and TNF in Ba103-treated mice (Figure 8a). Expression of TNF mRNA in colon tissue was significantly increased while other cytokines were only slightly changed in basophil-depleted mice (Figure $\mathbf{8 b}$ ). These data indicate that depletion of basophils results in a preferential induction of Th1 cells that is stable for prolonged periods of time and results in exacerbation of colitis with expression of more pro-inflammatory cytokines in the colon and plasma.

\section{Basophils suppress expression of Th1 cytokines in an IL-4- and IL-6-dependent manner}

We investigated in vitro which basophil-derived factors mediate suppression of Th1 cytokines (Figure 9). In the absence of basophils, activated Th cells produced large amounts of IL-2, IFN- $\gamma$, and TNF as measured by intracellular cytokine staining. Addition of basophils and their activation with IL-3 markedly suppressed expression of IL-2, IFN- $\gamma$, and TNF by T cells. Basophil-derived IL-4 and IL- 6 were both able to suppress IL- 2 and IFN- $\gamma$, and inhibition or deficiency of both cytokines was necessary to fully abrogate the inhibitory effects of basophils. By contrast, the combined action of basophilderived IL- 4 and IL- 6 was necessary to mediate the suppression of TNF, as shown by individual blockade of each cytokine and experiments with recombinant IL-4 and IL-6 (Figure 9).

\section{DISCUSSION}

Adoptive transfer of $\mathrm{T}$ cells into lymphopenic hosts results in a fast and pronounced proliferation of $\mathrm{T}$ cells and is a wellestablished model of murine chronic colitis. We report that basophils suppress the pro-inflammatory/Th1 phenotype of adoptively transferred $\mathrm{T}$ cells and thereby control development of colitis. SCID or RAG ${ }^{-1-}$ mice have normal numbers of basophils, but upon reconstitution with $\mathrm{CD} 4{ }^{+} \mathrm{CD} 62 \mathrm{~L}^{+}$ $\mathrm{T}$ cells, IL-3 plasma levels increase more than fivefold and basophils are markedly expanded. T-cell-derived IL-3 significantly contributes to expansion of basophils, as shown by adoptive transfer of T cells from IL-3-deficient mice. T cells and T-cell-derived factors (especially IL-3) also induce activation of basophils with release of IL-4 and IL-6, as shown by ex vivo culture of splenocytes and bone marrow cells from SCID mice reconstituted with wild-type T cells, IL- $3^{-1-} \mathrm{T}$ cells, or no $\mathrm{T}$ cells. After reconstitution of SCID mice with $\mathrm{CD} 4{ }^{+} \mathrm{CD} 62 \mathrm{~L}^{+}$ $\mathrm{T}$ cells, we noticed the preferential expansion of a basophil population in the bone marrow and spleen that was characterized by higher expression of FceR1. FACS sorting showed that these Fc\&R1 ${ }^{+}{ }^{+}$cells have typical properties of basophils, as they release large amounts of IL-4 and IL-6, suppress Th1 and induce Th2 responses in activated $\mathrm{CD} 4{ }^{+}$ $\mathrm{T}$ cells, and markedly enhance B-cell proliferation. Fc\&R1 ${ }^{++}$ cells were more active than classical basophils, suggesting that these cells might be preactivated or newly generated basophils.

Recently Fc\&R1 ${ }^{+}$dendritic cells were described in mediastinal lymph nodes after challenge with dust mite allergens. ${ }^{8}$ These cells could theoretically be depleted by the Fc\&R1 antibody MAR1, raising some concerns about the specificity of 


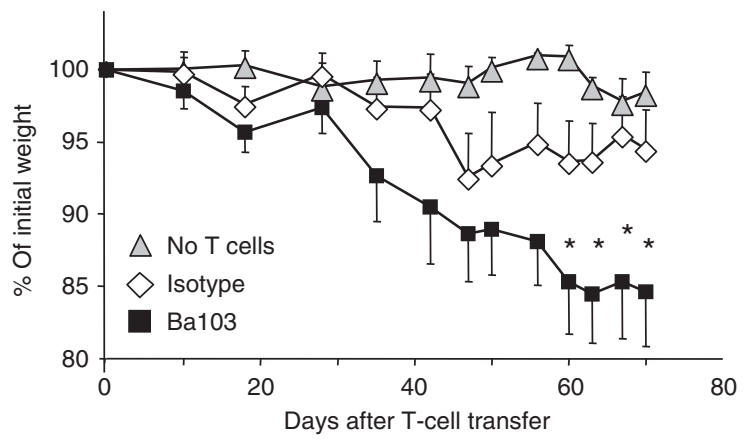

b $\quad$ Day 70

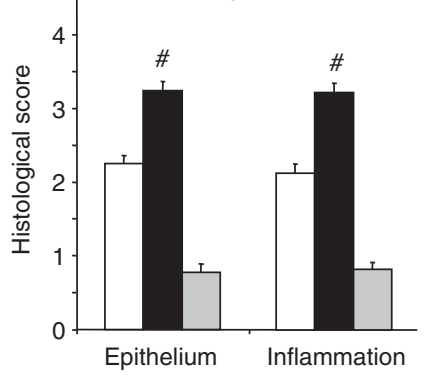

C
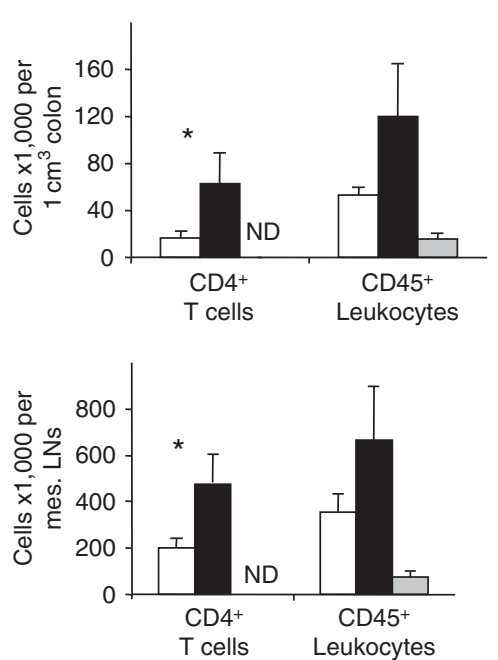

d

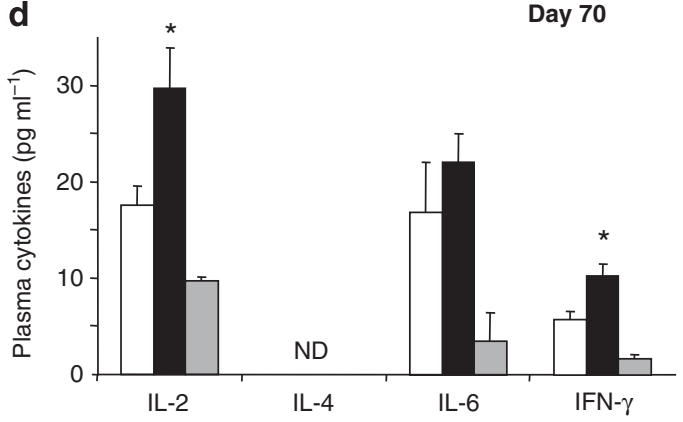

No T cells

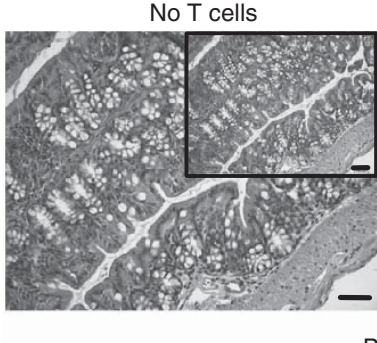

Isotype

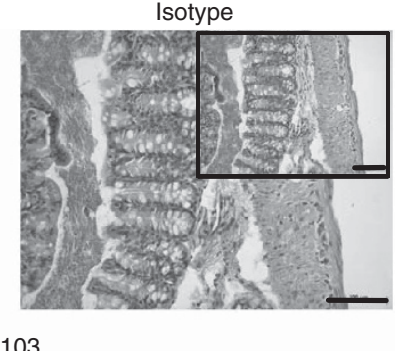

Ba103
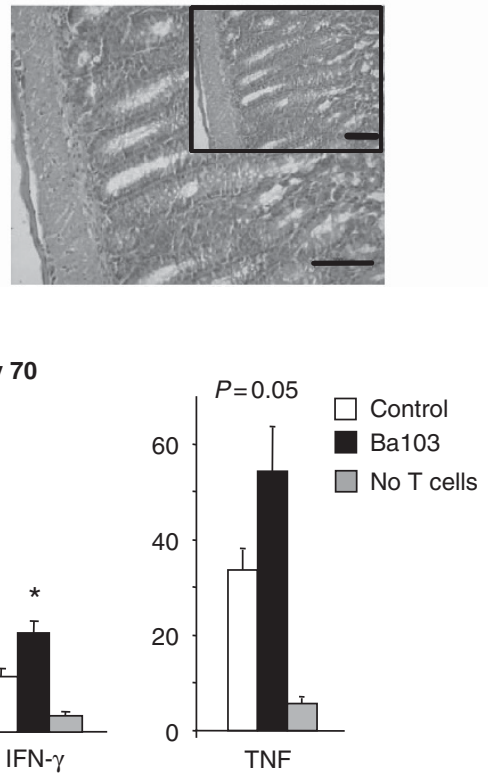

Figure 7 Depletion of basophils with Ba103 aggravates colitis in RAG2 ${ }^{-1-}$ mice. RAG2 ${ }^{-1-}$ mice were or were not depleted of basophils using a single intravenous injection $(30 \mu \mathrm{g})$ of the CD200R3 antibody Ba103 (black bars) or isotype control antibody (white bars) (eight mice per group) and reconstituted with $0.5 \times 10^{6} \mathrm{CD}^{+}{ }^{+} \mathrm{CD} 62 \mathrm{~L}+$ T cells from C57BL/6 mice 3 days later. A control group received no T cells (grey bars; four RAG2 ${ }^{-1-}$ mice). (a) The weight of the mice was measured until day 70 . (b) Epithelial damage and inflammation was quantified in colon sections. (c) The number of infiltrating $\mathrm{CD} 4{ }^{+} \mathrm{T}$ cells and CD45 ${ }^{+}$total leukocytes in colon and mesenteric lymph nodes (mes. LNs) was measured in single-cell suspensions of colon tissue and pooled mesenteric lymph nodes using counting beads. (d) All plasma cytokines at day 70 were quantified by cytometric bead array. Data are represented as mean \pm s.e.m. IFN, interferon; IL, interleukin; ND, not detected; TNF, tumor necrosis factor.

basophil depletion with MAR1. Although we were unable to detect these cells in SCID or RAG ${ }^{-I}$ mice, we used the antibody Ba103, directed against CD200R3, as an alternative method for depletion of basophils. In addition, MAR1 was also described to induce a weak depletion of mast cells, ${ }^{13}$ which is not the case with the antibody Ba103. ${ }^{40}$ Depletion of basophils was equally effective and nearly complete with MAR1 and Ba103. CD4 ${ }^{+} \mathrm{T}$ cells transferred into basophil-depleted mice showed a significantly higher expression of IL-2, TNF, and
IFN- $\gamma$ at day 8 and even in the long term the increased Th1 phenotype was preserved, although the number of basophils had returned to normal. The prolonged persistence of exacerbated Th1 responses might be explained by stable epigenetic changes induced during the rapid proliferation of $\mathrm{T}$ cells immediately after adoptive transfer. ${ }^{41}$ Basophil-depleted mice developed a more severe colitis with increased loss of weight, inflammation of the colon, and higher levels of proinflammatory Th1-specific cytokines in the plasma and colon. 
a
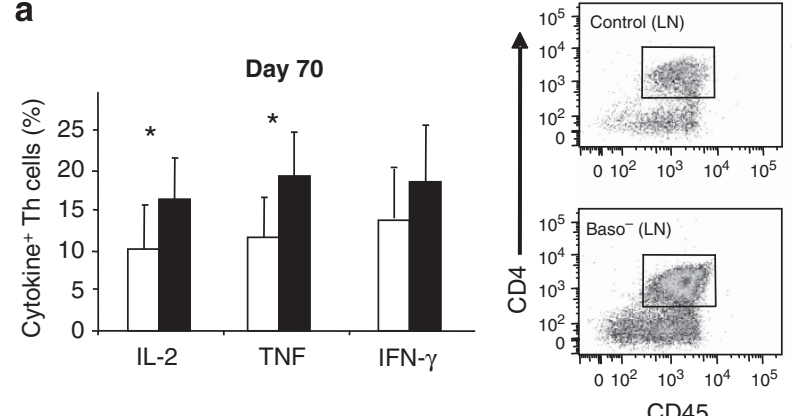

CD45

b

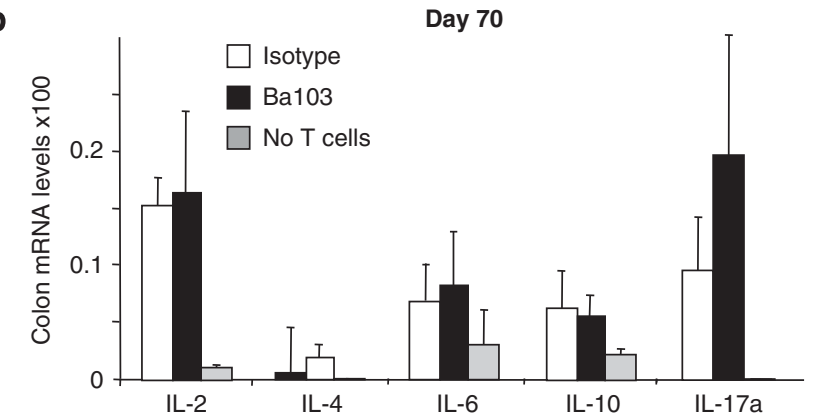

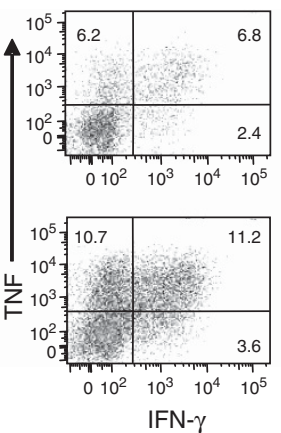
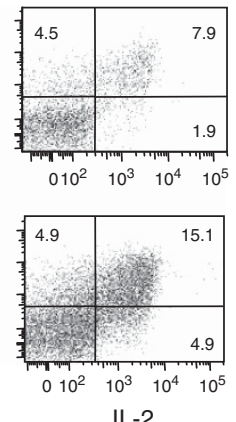

Day 70

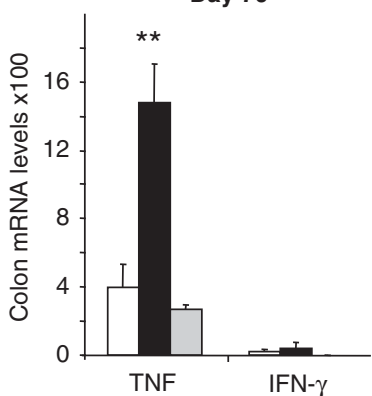

Figure 8 Altered T-cell phenotype and cytokine expression after depletion of basophils with Ba103. (a, b) On day 70 after induction of colitis as described in Figure 7, intracellular cytokine expression was measured in CD4 ${ }^{+} \mathrm{T}$ cells from pooled mesenteric lymph nodes (LNs; a). Cytokine expression in colon tissue was quantified by real-time PCR (b). Data are represented as mean \pm s.e.m. IFN, interferon; IL, interleukin; Th, T helper; TNF, tumor necrosis factor.

We have not seen a consistently reduced expression of Th2 cytokines like IL-4, IL-10, and IL-13 in basophil-depleted mice, most likely because Th2 levels were already very low in control mice. In vitro, we analyzed which basophil-derived factors suppress Th1 cytokines in $\mathrm{CD} 4{ }^{+} \mathrm{T}$ cells and found that basophil-derived IL-4 and IL-6 is necessary and sufficient to suppress IFN- $\gamma$ and TNF production by $\mathrm{CD} 4{ }^{+} \mathrm{T}$ cells, while suppression of TNF required the combined action of IL-4 and IL-6. These in vitro data, the release of IL-4 and IL-6 from basophils after reconstitution of SCID mice with wild-type T cells and the exacerbation of Th1 responses after depletion of basophils in reconstituted SCID mice, suggest that basophilderived IL-4 and IL-6 also restrict Th1 development in vivo, although we have not shown this directly.

A beneficial effect of basophils in autoimmunity was also observed in a model of serum-induced arthritis, where intravenous gammaglobulin indirectly activated basophils to release IL-4 and induced a beneficial Th2 response. $^{42}$ In addition, commensal bacteria in the intestine were recently shown to limit basophil development in the mouse. ${ }^{35}$ As colitis does not develop in germ-free mice, ${ }^{43}$ one could speculate that bacteria in the intestine limit basophil expansion and thereby contribute to development of the disease. There is also evidence that exposure to parasites protects from development of inflammatory bowel disease and is effective for the treatment of immune-mediated diseases. ${ }^{44-46}$ These observations could, in part, be mediated by parasite-induced, IL-3-mediated expansion of basophils. ${ }^{12}$

Our data indicate that basophils counter-regulate diseaseinducing Th1 responses that develop after adoptive transfer of
T cells into lymphopenic hosts and thereby control development of colitis. Depletion of basophils results in long-lasting upregulation of pro-inflammatory Th1 responses and exacerbation of colitis. These data show that physiological numbers of basophils modulate the T-cell phenotype in autoimmune diseases, especially during periods of T-cell expansion.

\section{METHODS}

Mice. Female SCID (CB17/Icr-Prkdc $c^{\text {scid } / I c r C r l) ~ a n d ~ B A L B / c ~ m i c e ~}$ were purchased from Charles River (Sulzfeld, Germany), female RAG $-2^{-1-}$ and C57BL/6N mice were from Taconic (Bomholt, Denmark). Mice deficient for IL- 4 and IL- 6 on a C57BL/6J background were obtained from Jackson Laboratory (Bar Harbor, ME). Doubledeficient mice were obtained by crossbreeding. Mice deficient for IL-3 (C.Cg-Il $<$ tm1Glli $>$ ) on a BALB/c background were obtained from RIKEN BRC (RBRC No. 02298; Tsukuba, Japan). Animals were housed under specific pathogen-free conditions. All animal experiments were performed according to institutional guidelines and German federal laws on animal protection.

In vivo depletion of basophils in SCID and $\mathrm{RAG}^{-1-}$ mice. Basophils were depleted by injection of $5 \mu \mathrm{g}$ anti-FceR1 twice daily intraperitoneally for 3 days (MAR1; eBioscience, San Diego, CA) ${ }^{13}$ or one intravenous injection of $30 \mu \mathrm{g}$ anti-CD200R3 (Ba103; Hycult, Uden, The Netherlands) as described by Obata et al. ${ }^{40}$ Due to variability of some lots of MAR1, each lot was tested. Controls received the same dose of isotype control antibody.

Isolation of naive $\mathrm{CD}^{+}{ }^{+\mathrm{CD} 2 \mathrm{~L}^{+}}{ }^{+} \mathrm{T}$ cells and induction of colitis. $\mathrm{CD} 4{ }^{+} \mathrm{T}$-cells from spleens of 8 -weeks-old BALB/c or C57BL/6N mice were isolated using the T-cell isolation kit I (Miltenyi Biotech, Bergisch-Gladbach, Germany). CD $4{ }^{+} \mathrm{CD}_{2} 2 \mathrm{~L}^{+} \mathrm{T}$ cells were subsequently separated using CD62L microbeads. Recipient mice were reconstituted by intraperitoneal injection of $2 \times 10^{6} \mathrm{CD}^{+} \mathrm{CD}^{+} 2 \mathrm{~L}^{+} \mathrm{T}$ 
a
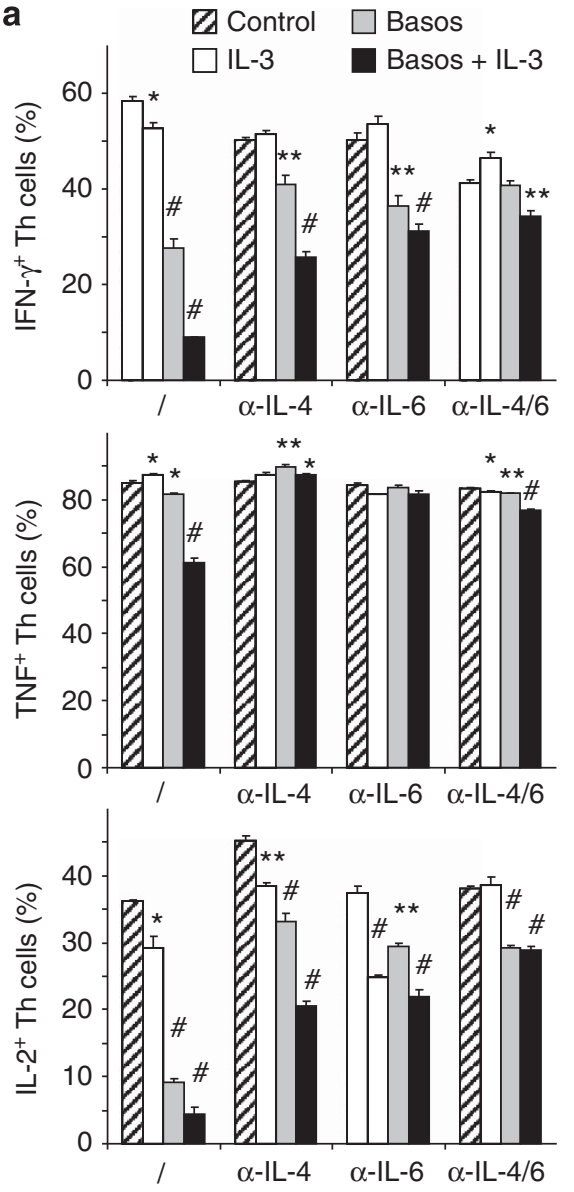

b
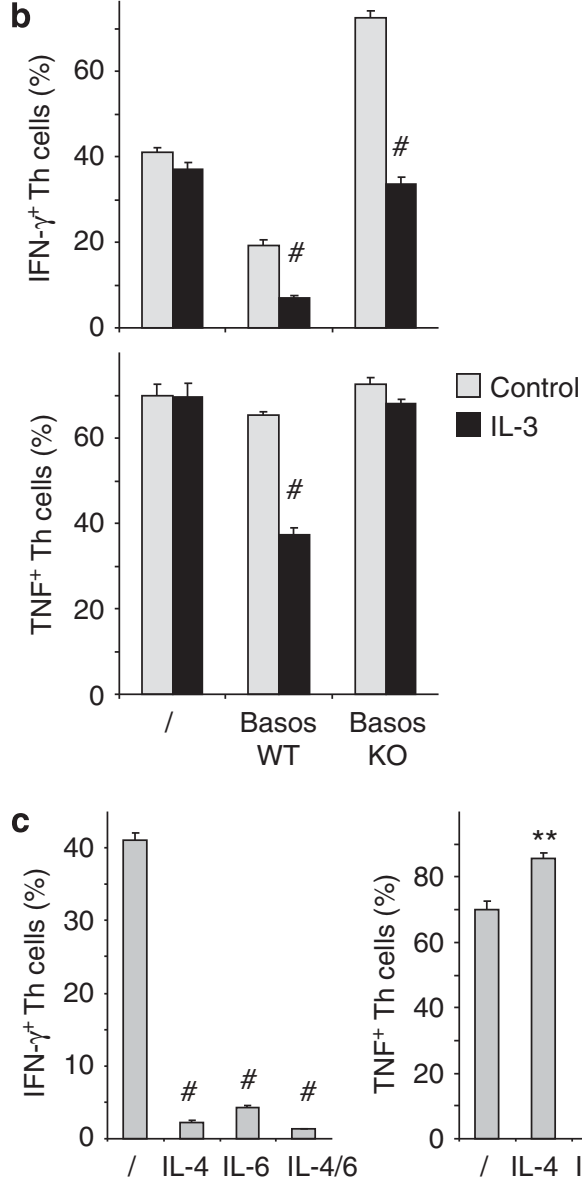
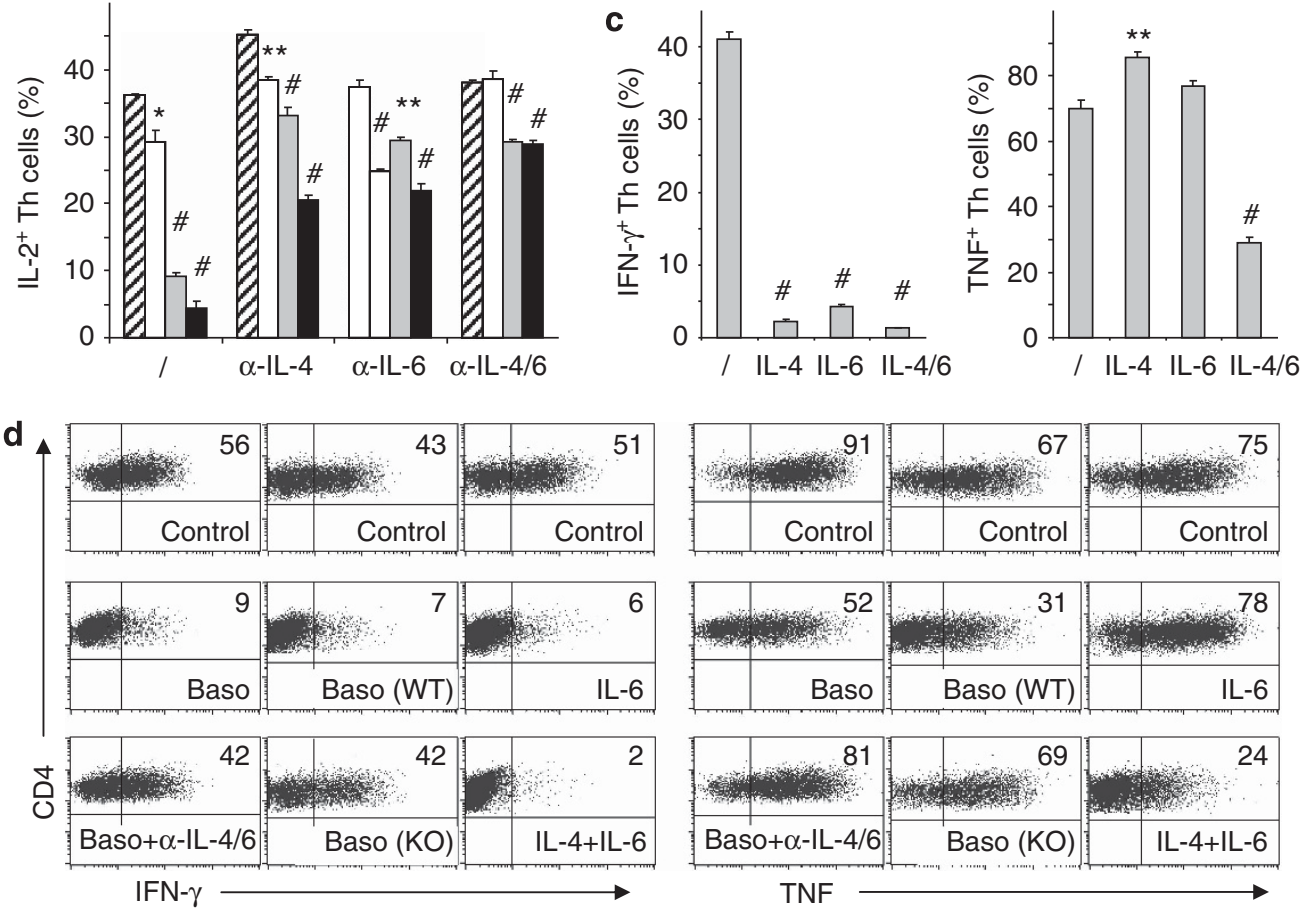

Figure 9 Basophils modify the phenotype of CD4 ${ }^{+}$T cells by the release of interleukin (IL)- 4 and IL-6. Purified CD4 ${ }^{+}$T cells (50,000 cells per well) from C57BL/6 mice were polyclonally activated with anti-CD3 in the presence of B cells (from C57BL/6; 50,000 cells per well) and additional factors as indicated. After 3 days, intracellular expression of interferon (IFN)- $\gamma$, tumor necrosis factor (TNF), and IL-2 was quantified in CD4 ${ }^{+}$T cells by flow cytometry. (a) Basophils (Basos) from bone marrow of C57BL/6 mice, IL-3, and blocking antibodies against IL-4 and IL-6 were added into the culture as indicated. (b) Basophils (Basos) from wild-type mice (WT) or IL-4 and IL-6 double knock-out mice on a C57BL/6 background (KO) were added in a culture with or without IL-3. (c) The impact of recombinant IL-4 and IL-6 or a combination of both cytokines on the T-cell phenotype was analyzed. (d) Representative FACS (fluorescence-activated cell sorter)-plots of culture conditions with IL-3 as described in the panels above. One out of two representative experiments is shown. Data are represented as mean \pm s.e.m. Th, T helper.

cells for short-term experiments or $0.5 \times 10^{6} \mathrm{CD} 4{ }^{+} \mathrm{CD}_{22} \mathrm{~L}^{+} \mathrm{T}$ cells for long-term experiments as indicated in the figure legends.

Extracellular flow cytometry. Cells were preincubated for $15 \mathrm{~min}$ on ice with Fc-block (clone $2.4 \mathrm{G} 2 ; 5 \mu \mathrm{g} \mathrm{ml}^{-1}$ ) and then stained with combinations of directly labelled antibodies for $25 \mathrm{~min}$. The following antibodies were obtained from BD Biosciences (Heidelberg, Germany) and eBioscience: anti-CD4 (clone RM4-5), anti-CD11c (clone HL3),
anti-CD45 (cone 30-F11), anti-CD49b (clone HM $\alpha 2$ ), anti-IL-2 (clone JES6-5H4), anti-TNF (clone MP6-XT22), anti-IFN- $\gamma$ (clone XMG1.2), and anti-FceR1 (clone MAR1). Red blood cells were lysed with FACS-lysing solution (BD Biosciences), and samples analyzed on a FACSCalibur with CellQuest software (BD Biosciences) or a FACSCanto II (BD Biosciences) with FlowJo software (Tree Star, Ashland, OR). For analysis, leukocytes were first gated according to their FSC-SSC properties and expression of surface markers shown on 
total leukocytes. The number of cells was quantified using counting beads (Invitrogen, Darmstadt, Germany). For flow cytometric analysis of colon tissue, $1 \mathrm{~cm}^{3}$ of colon was flushed with phosphate-buffered saline, cut into small pieces, digested with collagenase type I from Clostridium histolyticum (Sigma-Aldrich, Munich, Germany, $1 \mu \mathrm{g} \mathrm{ml}^{-1}$ ) for $30 \mathrm{~min}$ at $37^{\circ} \mathrm{C}$ and applied to a $70-\mu \mathrm{m}$ cell strainer for staining as mentioned.

Intracellular staining of cytokines. Splenocytes and mesenteric lymph node cells were incubated with phorbol 12-myristate 13-acetate $\left(10 \mathrm{ng} \mathrm{ml}^{-1}\right)$ and ionomycin $\left(1 \mu \mathrm{g} \mathrm{ml}^{-1}\right)$ for $4 \mathrm{~h}$ at $37^{\circ} \mathrm{C}$. Brefeldin $\mathrm{A}$ $\left(5 \mu \mathrm{g} \mathrm{ml}^{-1}\right)$ was added during the final $2.5 \mathrm{~h}$ of culture. Cells were stained extracellular with anti-CD4 (RM4-5) and anti-CD45 (30-F11), treated with Fix-Perm and Perm-Wash solutions (BD Biosciences) and after intracellular preincubation with Fc-block $\left(5 \mu \mathrm{g} \mathrm{ml}^{-1}\right)$ stained intracellular with antibodies against IL-2, IFN- $\gamma$, TNF, and IL-17a $\left(2-5 \mu \mathrm{g} \mathrm{ml}^{-1}\right)$. For analysis of intracellular cytokines, leukocytes were first gated by FSC-SSC properties and then a second gate was set on $\mathrm{CD} 45^{+} \mathrm{CD} 4{ }^{+}$cells.

Quantification of plasma cytokines. TNF, IL-2, IL-3, IL-4, IL-6, and IFN- $\gamma$ were quantified in plasma using the BD Cytometric Flex Set (BD Biosciences) and by enzyme-linked immunosorbent assay (ELISA; OptEIA; BD Biosciences).

Quantification of IL-4 and IL-6 in cultures of spleen and bone marrow cells of SCID mice on day 14 after reconstitution with $T$ cells. Bone marrow cells or spleen cells ( 2 Mio cells perwell in a total volume of $200 \mu \mathrm{l}$ medium) were cultured for $12 \mathrm{~h}$ in medium with phosphate-buffered saline or IL-3 $\left(10 \mathrm{ng} \mathrm{ml}^{-1}\right)$ directly on ELISA plates (Nunc, Munich, Germany) coated with anti-IL-4 to avoid consumption of soluble IL-4. The culture medium consisted of RPMI1640 with $10 \%$ heat-inactivated fetal calf serum, Penicillin/Streptomycin, non-essential amino acids, $1 \mathrm{~mm} \mathrm{Na-pyruvat,} 100 \mu \mathrm{m}$ Hepes (4(2-hydroxyethyl)-1-piperazineethanesulfonic acid), and $0.1 \mu \mathrm{M}$ mercaptoethanol. For depletion of basophils, splenocytes or bone marrow cells (collected from the femur and tibia bones) were stained with phycoerythrin-labeled anti-FceRI (eBioscience) and removed with magnetic beads directed against phycoerythrin (Miltenyi Biotech) using LD columns (Miltenyi Biotech). Sham depletion was performed with LD columns after incubating the cells with phosphate-buffered saline and anti-phycoerythrin beads. IL- 4 and IL- 6 were measured with ELISA kits (OptEIA; BD Bioscience).

In vivo cytokine IL-3 capture assay. Mice were injected intravenously with $10 \mu \mathrm{g}$ of dialyzed, biotin-labelled anti-IL-3 antibody (MP243D11; BD Biosciences) $3 \mathrm{~h}$ before blood sample acquisition in analogy to an established protocol. ${ }^{47}$ The plasma level of IL-3 was measured by ELISA (BD Biosciences).

Real-time PCR analysis of colon sections. The expression of each gene was quantified in relation to HPRT (hypoxanthine-guanine phosphoribosyltransferase) using TaqMan Cytokine Gene Expression kits (Applied Biosystems, Foster City, CA, USA). The following Taqman probes were used: 5'-GCCCAAGCAGGCCACAGAATT GAAA- $3^{\prime}$ (IL-2); 5' -ACAGCAACGAAGAACACCACAGAGA-3 ${ }^{\prime}$ (IL-4); $5^{\prime}$-AAACTGGATATAATCAGGAAATTTG-3' (IL-6); $5^{\prime}$-TA ATGCAGGACTTTAAGGGTTACTT-3' (IL-10); $5^{\prime}$-CTGGACTC TCCACCGCAATGAAGAC-3' (IL-17A); $5^{\prime}$-TGCCAAGTTTGA GGTCAACAACCCA-3' (IFN- $\gamma) ; 5^{\prime}$-TCCCCAAAGGGATGAGAA GTTCCCA-3' (TNF); and 5'-ACTGATTATGGACAGGACTGAA AGA-3' (Hprt1).

Isolation and culture of lymphocytes with basophils. CD4 ${ }^{+} \mathrm{T}$ cells and $\mathrm{B}$ cells were isolated from the spleens of $\mathrm{BALB} / \mathrm{c}$ mice with magnetic microbeads with a purity of 95\% (Miltenyi Biotech). Basophils were isolated from the bone marrow with magnetic microbeads against CD49b (Miltenyi Biotech), and FceR1 ${ }^{+}$and FceR $1^{++}$basophils were further separated by FACS-sorting
(FACSAria, BD Biosciences). CD ${ }^{+}$T cells $(50,000$ cells per well) were cultured with the same number of CFSE (carboxyfluorescein succinimidyl ester)-labelled $\mathrm{B}$ cells and polyclonally activated with antiCD3 $\left(0.5 \mu \mathrm{g} \mathrm{ml}^{-1}\right.$; $\left.145-2 \mathrm{C} 11\right)$ for 3 days. Basophils $(2,000$ cells per well, if not otherwise indicated), IL-3 $\left(10 \mathrm{ng} \mathrm{ml}^{-1}\right.$, Peprotech, Hamburg, Germany), IL-4 (5 $\mathrm{ng} \mathrm{ml}^{-1}$, Peprotech), IL-6 (10 $\mathrm{ng} \mathrm{ml}^{-1}$, Peprotech), anti-IL-4 (15 $\mu \mathrm{g} \mathrm{ml}^{-1}$, Clone 30340, R\&D Systems, Weisbaden, Germany) and anti-IL-6 $\left(15 \mu \mathrm{g} \mathrm{ml}^{-1}\right.$, Clone MP520F3, $\mathrm{R} \& \mathrm{D}$ Systems) were added as indicated. Cell culture was performed in 96-well round-bottomed plates in a total volume of $200 \mu \mathrm{l}$ medium. The culture medium consisted of RPMI-1640 with 10\% heatinactivated fetal calf serum, Penicillin/Streptomycin, non-essential amino acids, $1 \mathrm{~mm}$ Na-pyruvat, $100 \mu \mathrm{M}$ Hepes, and $0.1 \mu \mathrm{M}$ mercaptoethanol.

Histology. Cross-sections of the colon were stained with haematoxylin-eosin. The degree of inflammatory infiltrate and mucosal architecture were independently graded from 0 to 4 on three sections per mouse in a blinded fashion. ${ }^{48}$ Inflammatory infiltrate was evaluated with 0 -none; 1 -focal circumferential; 2-mild circumferential; 3-moderate circumferential; and 4-severe. Mucosal architecture was evaluated with 0 -intact; 1 - focal loss of goblet cells; 2-focally damaged architecture and extensive loss of goblet cells; 3-damaged architecture; and 4-loss of architecture.

Statistics. Error bars indicate the s.e.m. in all the figures. Cell culture experiments were performed in triplicates. $P$ values for significance were calculated with a one-sided Student's $t$-test and indicated with ${ }^{*}(P<0.05),{ }^{*}(P<0.01),{ }^{*}(P<0.001)$ or NS (not significant).

SUPPLEMENTARY MATERIAL is linked to the online version of the paper at http://www.nature.com/mi

\section{ACKNOWLEDGEMENTS}

We thank Glenn Dranoff for permission to use the IL-3-deficient mice. We thank Maria Hutterer for help in histology, Rüdiger Eder and Jasmin Stahl for support in FACS-sorting, and Klaus Stark for help with real-time PCR. This work was supported by grants from the Deutsche Forschungsgemeinschaft (M.M.).

\section{DISCLOSURE}

The authors declared no conflict of interest.

c 2014 Society for Mucosal Immunology

\section{REFERENCES}

1. Wedemeyer, J. \& Galli, S.J. Mast cells and basophils in acquired immunity. Br. Med. Bull. 56, 936-955 (2000).

2. Khodoun, M.V., Orekhova, T., Potter, C., Morris, S. \& Finkelman, F.D. Basophils initiate IL-4 production during a memory T-dependent response. J. Exp. Med. 200, 857-870 (2004).

3. Oh, K., Shen, T., Le, G.G. \& Min, B. Induction of Th2 type immunity in a mouse system reveals a novel immunoregulatory role of basophils. Blood 109, 2921-2927 (2007).

4. Sokol, C.L., Barton, G.M., Farr, A.G. \& Medzhitov, R. A mechanism for the initiation of allergen-induced Thelper type 2 responses. Nat. Immunol. 9 , 310-318 (2008)

5. Min, B. et al. Basophils produce IL-4 and accumulate in tissues after infection with a Th2-inducing parasite. J. Exp. Med. 200, 507-517 (2004).

6. Zheng, W. \& Flavell, R.A. The transcription factor GATA-3 is necessary and sufficient for Th2 cytokine gene expression in CD4 Tcells. Cell 89, 587-596 (1997).

7. Diehl, S. et al. Induction of NFATc2 expression by interleukin 6 promotes T helper type 2 differentiation. J. Exp. Med. 196, 39-49 (2002).

8. Hammad, H. et al. Inflammatory dendritic cells-not basophils-are necessary and sufficient for induction of Th2 immunity to inhaled house dust mite allergen. J. Exp. Med. 207, 2097-2111 (2010). 
9. Ohnmacht, C., Schwartz, C., Panzer, M., Schiedewitz, I., Naumann, R. \& Voehringer, D. Basophils orchestrate chronic allergic dermatitis and protective immunity against helminths. Immunity 33, 364-374 (2010).

10. Sullivan, B.M. et al. Genetic analysis of basophil function in vivo. Nat. Immunol. 12, 527-535 (2011).

11. Tang, H. et al. The Thelper type 2 response to cysteine proteases requires dendritic cell-basophil cooperation via ROS-mediated signaling. Nat. Immunol. 11, 608-617 (2010).

12. Lantz, C.S. et al. Role for interleukin-3 in mast-cell and basophil development and in immunity to parasites. Nature 392, 90-93 (1998).

13. Denzel, A. et al. Basophils enhance immunological memory responses. Nat. Immunol. 9, 733-742 (2008).

14. Mack, M. et al. Identification of antigen-capturing cells as basophils. J. Immunol. 174, 735-741 (2005).

15. Valent, P., Besemer, J., Muhm, M., Majdic, O., Lechner, K. \& Bettelheim, P. Interleukin 3 activates human blood basophils via high-affinity binding sites. Proc. Natl. Acad. Sci. USA 86, 5542-5546 (1989).

16. Ohnmacht, C. \& Voehringer, D. Basophil effector function and homeostasis during helminth infection. Blood 113, 2816-2825 (2009).

17. Kim, S., Prout, M., Ramshaw, H., Lopez, A.F., LeGros, G. \& Min, B. Cutting edge: basophils are transiently recruited into the draining lymph nodes during helminth infection via IL-3, but infection-induced Th2 immunity can develop without basophil lymph node recruitment or IL-3. J. Immunol. 184, 1143-1147 (2010).

18. Shen, T. et al. Tcell-derived IL-3 plays key role in parasite infection-induced basophil production but is dispensable for in vivo basophil survival. Int. Immunol. 20, 1201-1209 (2008).

19. Schroeder, J.T., Chichester, K.L. \& Bieneman, A.P. Human basophils secrete IL-3: evidence of autocrine priming for phenotypic and functional responses in allergic disease. J. Immunol. 182, 2432-2438 (2009).

20. Bruhl, H. et al. Important role of interleukin-3 in the early phase of collageninduced arthritis. Arthritis Rheum. 60, 1352-1361 (2009).

21. Didichenko, S.A., Spiegl, N., Brunner, T. \& Dahinden, C.A. IL-3 induces a Pim1-dependent antiapoptotic pathway in primary human basophils. Blood 112, 3949-3958 (2008).

22. Baumgart, D.C. \& Carding, S.R. Inflammatory bowel disease: cause and immunobiology. Lancet 369, 1627-1640 (2007).

23. Baumgart, D.C. \& Sandborn, W.J. Inflammatory bowel disease: clinical aspects and established and evolving therapies. Lancet 369, 1641-1657 (2007).

24. Morrissey, P.J., Charrier, K., Braddy, S., Liggitt, D. \& Watson, J.D. CD4 + T cells that express high levels of CD45RB induce wasting disease when transferred into congenic severe combined immunodeficient mice. Disease development is prevented by cotransfer of purified CD4 + T cells. J. Exp. Med. 178, 237-244 (1993).

25. Ito, H. \& Fathman, C.G. CD45RBhigh CD4 + T cells from IFN-gamma knockout mice do not induce wasting disease. J. Autoimmun. 10, 455-459 (1997).

26. Totsuka, T. et al. Therapeutic effect of anti-OX40L and anti-TNF-alpha MAbs in a murine model of chronic colitis. Am. J. Physiol. Gastrointest. Liver Physiol. 284, G595-G603 (2003).

27. Powrie, F., Leach, M.W., Mauze, S., Menon, S., Caddle, L.B. \& Coffman, R.L. Inhibition of Th1 responses prevents inflammatory bowel disease in scid mice reconstituted with CD45RBhi CD4 + T cells. Immunity $\mathbf{1}$, 553-562 (1994).
28. Becker, C. et al. Cutting edge: IL-23 cross-regulates IL-12 production in T cell-dependent experimental colitis. J. Immunol. 177, 2760-2764 (2006).

29. Izcue, A. et al. Interleukin-23 restrains regulatory Tcell activity to drive Tcelldependent colitis. Immunity 28, 559-570 (2008).

30. Wirtz, S. et al. Cutting edge: chronic intestinal inflammation in STAT-4 transgenic mice: characterization of disease and adoptive transfer by TNFplus IFN-gamma-producing CD4 $+\mathrm{T}$ cells that respond to bacterial antigens. J. Immunol. 162, 1884-1888 (1999).

31. Berg, D.J. et al. Enterocolitis and colon cancer in interleukin-10-deficient mice are associated with aberrant cytokine production and $\mathrm{CD} 4(+) \mathrm{TH} 1-$ like responses. J. Clin. Invest. 98, 1010-1020 (1996).

32. Kuhn, R., Lohler, J., Rennick, D., Rajewsky, K. \& Muller, W. Interleukin-10deficient mice develop chronic enterocolitis. Cell 75, 263-274 (1993).

33. Siracusa, M.C. et al. TSLP promotes interleukin-3-independent basophil haematopoiesis and type 2 inflammation. Nature 477, 229-233 (2011).

34. Wada, T. et al. Selective ablation of basophils in mice reveals their nonredundant role in acquired immunity against ticks. J. Clin. Invest. 120, 2867-2875 (2010).

35. Hill, D.A. et al. Commensal bacteria-derived signals regulate basophil hematopoiesis and allergic inflammation. Nat. Med. 18, 538-546 (2012).

36. Yoshimoto, T. et al. Basophils contribute to $T(H) 2-l g E$ responses in vivo via $\mathrm{IL}-4$ production and presentation of peptide-MHC class II complexes to CD4 + T cells. Nat. Immunol. 10, 706-712 (2009).

37. Chen, $\mathrm{K}$. et al. Immunoglobulin $\mathrm{D}$ enhances immune surveillance by activating antimicrobial, proinflammatory and B cell-stimulating programs in basophils. Nat. Immunol. 10, 889-898 (2009).

38. Rodriguez Gomez, M., Talke, Y., Goebel, N., Hermann, F., Reich, B. \& Mack, M. Basophils support the survival of plasma cells in mice. J. Immunol. 185, 7180-7185 (2010).

39. Charles, N., Hardwick, D., Daugas, E., Illei, G.G. \& Rivera, J. Basophils and the $\mathrm{T}$ helper 2 environment can promote the development of lupus nephritis. Nat. Med. 16, 701-707 (2010).

40. Obata, K. et al. Basophils are essential initiators of a novel type of chronic allergic inflammation. Blood 110, 913-920 (2007).

41. Ansel, K.M., Lee, D.U. \& Rao, A. An epigenetic view of helper T cell differentiation. Nat. Immunol. 4, 616-623 (2003).

42. Anthony, R.M., Kobayashi, T., Wermeling, F. \& Ravetch, J.V. Intravenous gammaglobulin suppresses inflammation through a novel $\mathrm{T}(\mathrm{H}) 2$ pathway. Nature 475, 110-113 (2011).

43. Niess, J.H., Leithauser, F., Adler, G. \& Reimann, J. Commensal gut flora drives the expansion of proinflammatory CD4 T cells in the colonic lamina propria under normal and inflammatory conditions. J. Immunol. 180, 559-568 (2008).

44. Weinstock, J.V. \& Elliott, D.E. Helminths and the IBD hygiene hypothesis. Inflamm. Bowel. Dis. 15, 128-133 (2009).

45. Summers, R.W., Elliott, D.E., Urban, Jr. J.F., Thompson, R. \& Weinstock, J.V. Trichuris suis therapy in Crohn's disease. Gut 54, 87-90 (2005).

46. Summers, R.W., Elliott, D.E., Urban, Jr. J.F., Thompson, R.A. \& Weinstock, J.V. Trichuris suis therapy for active ulcerative colitis: a randomized controlled trial. Gastroenterology 128, 825-832 (2005).

47. Finkelman, F.D. \& Morris, S.C. Development of an assay to measure in vivo cytokine production in the mouse. Int. Immunol. 11, 1811-1818 (1999).

48. Obermeier, F. et al. In vivo CpG DNA/toll-like receptor 9 interaction induces regulatory properties in $\mathrm{CD} 4+\mathrm{CD} 62 \mathrm{~L}+\mathrm{T}$ cells which prevent intestinal inflammation in the SCID transfer model of colitis. Gut 54, 1428-1436 (2005). 